${ }^{1}$ Department of Food Science and Technology, Tokyo University of Fisheries, 4-5-7 Konan, Minato-ku, Tokyo 108-8477, Japan

2 Marine Biotechnology Institute, Kamaishi Laboratories, 3-75-1 Heita, Kamaishi City, Iwate 026-0001, Japan

\section{Phylogenetic study of the genus Oceanospirillum based on 165 rRNA and gyrB genes: emended description of the genus Oceanospirillum, description of Pseudospirillum gen. nov., Oceanobacter gen. nov. and Terasakiella gen. nov. and transfer of Oceanospirillum jannaschii and Pseudomonas stanieri to Marinobacterium as Marinobacterium jannaschii comb. nov. and Marinobacterium stanieri comb. nov.}

\author{
Masataka Satomi, ${ }^{1}+$ Bon Kimura, ${ }^{1}$ Tohru Hamada, ${ }^{2}$ Shigeaki Harayama ${ }^{2}$ \\ and Tateo Fujii ${ }^{1}$
}

Author for correspondence: Bon Kimura. Tel: +81354630603 . Fax: +81354630602.
e-mail: kimubo@tokyo-u-fish.ac.jp

The phylogenetic relationships of Oceanospirillum strains were analysed by using the nucleotide sequences of 16S rRNA and gyrB genes. Results from sequence analysis demonstrated that the Oceanospirillum core group consisted of four species, Oceanospirillum linum, Oceanospirillum maris, Oceanospirillum beijerinckii and Oceanospirillum multiglobuliferum, with enough distance to separate them as different species. However, four other Oceanospirillum species occupied taxonomic positions separate from the Oceanospirillum core group: Oceanospirillum jannaschii, Oceanospirillum japonicum and Oceanospirillum kriegii in the $\gamma$-Proteobacteria and Oceanospirillum pusillum in the $\alpha$-Proteobacteria. Oceanospirillum jannaschii clustered with

Marinobacterium georgiense, Pseudomonas iners and Pseudomonas stanieri on the basis of phylogenetic analysis of $16 S$ rRNA and gyrB genes. The other three species did not cluster with known genera. Also, the sequence similarity values of the gyrB genes between the three subspecies of Oceanospirillum maris and those between the two subspecies of Oceanospirillum beijerinckii were above $\mathbf{9 9} \%$. The close relationships between the subspecies of Oceanospirillum maris and of Oceanospirillum beijerinckii were further supported by similar physiological properties and high DNA-DNA hybridization values, suggesting that these subspecies should not be regarded as valid. From these results, Oceanospirillum sensu stricto should be defined to consist of Oceanospirillum linum, Oceanospirillum maris, Oceanospirillum beijerinckii and Oceanospirillum multiglobuliferum. We propose to create the following new genera: Pseudospirillum gen. nov. for Oceanospirillum japonicum as Pseudospirillum japonicum comb. nov.; Oceanobacter gen. nov. for Oceanospirillum kriegii as Oceanobacter kriegii comb. nov.; and Terasakiella gen. nov. for Oceanospirillum pusillum as Terasakiella pusilla comb. nov. The transfer is

†Present address: National Research Institute of Fisheries Science, 2-12-4 Fukuura, Kanazawa-ku, Yokohama, Kanagawa 236-8648, Japan. Abbreviation: PHB, poly- $\beta$-hydroxybutyrate.

The DDBJ accession numbers for the gyrB sequences reported in this paper are AB014929, AB014932-AB014937, $A B 032183-A B 032190$ and AB048519-AB048521, as detailed in Table 1. 


\begin{abstract}
proposed of Oceanospirillum jannaschii and Pseudomonas stanieri to Marinobacterium as Marinobacterium jannaschii comb. nov. and Marinobacterium stanieri comb. nov. Furthermore, Pseudomonas iners should be reclassified as a strain of Marinobacterium georgiense. Finally, the subspecies of Oceanospirillum maris ( 0 . maris subsp. maris, 0 . maris subsp. hiroshimense and 0 . maris subsp. williamsae) and Oceanospirillum beijerinckii ( $O$. beijerinckii subsp. beijerinckii and 0 . beijerinckii subsp. pelagicum) should be combined as Oceanospirillum maris and Oceanospirillum beijerinckii, respectively.
\end{abstract}

Keywords: Oceanospirillum, Oceanobacter, Pseudospirillum, Marinobacterium, Terasakiella

\section{INTRODUCTION}

The genus Oceanospirillum was established by the division of the genus Spirillum Ehrenberg 1832 by Hylemon et al. (1973). Its members were isolated from the ocean, from putrid marine shellfish (Terasaki, 1972, 1973, 1975, 1979; Watanabe, 1959) and from coastal sea water (Baumann et al., 1972; Hylemon et al., 1973; Linn \& Krieg, 1978; Williams \& Rittenberg, 1957), and are presently known to be distributed ubiquitously in marine environments. According to Holt et al. (1994), all helical, halophilic, chemoorganotrophic and aerobic bacteria belong to the genus Oceanospirillum, which currently consists of eight species, two of which include a total of five subspecies. However, there is much intrageneric diversity in this group, as revealed by rRNA-DNA hybridization experiments (Pot et al., 1989, 1992), fatty acid analysis (Sakane \& Yokota, 1994) and the compositions of isoprenoid quinones (Sakane \& Yokota, 1994) and polyamines (Hamana et al., 1994). In a previous study, based on analysis of $16 \mathrm{~S}$ rRNA gene sequences (16S rDNA), Oceanospirillum minutulum was transferred to a new genus, Marinospirillum (Satomi et al., 1998). However, the taxonomic positions of four species, Oceanospirillum jannaschii, Oceanospirillum japonicum, Oceanospirillum kriegii and Oceanospirillum pusillum, and the validity of the subspecies belonging to Oceanospirillum maris and Oceanospirillum beijerinckii remained to be clarified. In order to understand better the phylogenetic relationships of these organisms, it is preferable to perform phylogenetic analysis based on multiple gene sequences. Several genes, such as gyr $B$ and $r p o D$, and the internal transcribed spacer region of rRNA genes, have been evaluated as alternatives to the $16 \mathrm{~S}$ rDNA sequence (Takewaki et al., 1994; Viale et al., 1994; Yamamoto \& Harayama, 1995, 1996, 1998; Morse et al., 1996; Edgell et al., 1997). Notably, proteinencoding genes are known to evolve much faster than 16S rDNA and may thus provide precise phylogenetic information about closely related species or subspecies. In this study, we determined the $\operatorname{gyr} B$ nucleotide sequences of strains in the genus Oceanospirillum to facilitate the study of their phylogenetic relationships.

\section{METHODS}

Bacterial strains and growth conditions. The bacterial strains investigated are listed in Table 1. Oceanospirillum and its related strains were obtained from the Institute for Fermentation Osaka (IFO), the ATCC, the Institute of Applied Microbiology (IAM) and Dr Y. Terasaki (formerly of Suzugamine Women's College, Hiroshima, Japan). These strains were maintained by stab culture in medium 325 (IFO, 1996) semi-solid agar, which contained the following ingredients: $1.0 \%(\mathrm{w} / \mathrm{v})$ polypeptone (Difco), $0.2 \%$ yeast extract (Difco), $0.05 \% \mathrm{MgSO}_{4} .7 \mathrm{H}_{2} \mathrm{O}, 75 \%(\mathrm{w} / \mathrm{v})$ sea water, $25 \%(\mathrm{w} / \mathrm{v})$ distilled water and $0.2 \%$ agar. The $\mathrm{pH}$ was adjusted to $7 \cdot 2$ with $1.0 \mathrm{M} \mathrm{NaOH}$. The cultures were incubated for 3 days at $20{ }^{\circ} \mathrm{C}$. In order to obtain large amounts of cells, cultures were incubated in medium 325 broth at 90 r.p.m. on a rotary shaker.

Phenotypic characteristics. Tolerance of $\mathrm{NaCl}$ and growth at various temperatures were tested according to Terasaki (1972). Glycine tolerance and production of catalase, DNase and RNase were determined according to Hylemon et al. (1973). Other physiological and biochemical tests were performed by using API 20E, API 20NE and API ZYM test kits (bioMérieux), which were prepared according to the manufacturer's specifications, except that bacterial strains were suspended in $3 \% \mathrm{NaCl}$ solution.

DNA preparation and DNA-DNA homology. Late exponential phase cultures were centrifuged and then cell pellets were suspended in TE buffer ( $\mathrm{pH} 8.0$ ) to extract chromosomal DNA. Cell suspensions were treated with $0.5 \%$ SDS for lysis. Chromosomal DNA was purified by standard methods (Sambrook et al., 1989). DNA-DNA homology was studied by microplate hybridization methods (Ezaki et al., 1989) with photobiotin labelling and colorimetric detection as described previously (Satomi et al., 1997).

gyrB nucleotide sequencing and phylogenetic analysis. The $1.2 \mathrm{kbp}$ nucleotide sequences of the gyrB genes of Oceanospirillum species and related organisms (covering base positions 274-1525, Escherichia coli numbering) were amplified by using PCR with universal primer sets (Yamamoto \& Harayama, 1995) and sequenced. The PCR conditions were as described by Yamamoto \& Harayama (1995). The PCR products were visualized by electrophoresis with $1.5 \%(\mathrm{w} / \mathrm{v})$ agarose gel (Nippon Gene) stained with ethidium bromide. 
Table 1. Strains investigated in this study

The $g y r B$ genes were sequenced in this study.

\begin{tabular}{|c|c|c|}
\hline \multirow[t]{2}{*}{ Strain } & \multicolumn{2}{|c|}{ Accession number } \\
\hline & 16S rRNA & $\operatorname{gyr} B$ \\
\hline Oceanospirillum linum IFO $15448^{\mathrm{T}}\left(=\right.$ ATCC $\left.11336^{\mathrm{T}}\right)$ & M22365 & AB014935 \\
\hline Oceanospirillum linum IFO 15449 (= ATCC 12753) & - & - \\
\hline Oceanospirillum maris subsp. maris ATCC $27509^{\mathrm{T}}$ & AB006771 & AB014936 \\
\hline Oceanospirillum maris subsp. hiroshimense IFO $13616^{\mathrm{T}}$ & $\mathrm{AB} 006762$ & AB032183 \\
\hline Oceanospirillum maris subsp. williamsae IFO $15468^{\mathrm{T}}\left(=\right.$ ATCC $\left.29547^{\mathrm{T}}\right)$ & AB006763 & AB032184 \\
\hline Oceanospirillum beijerinckii subsp. beijerinckii IFO $15445^{\mathrm{T}}\left(=\mathrm{ATCC} 12754^{\mathrm{T}}\right)$ & AB006760 & AB032185 \\
\hline Oceanospirillum beijerinckii subsp. pelagicum $\mathrm{IFO} 13612^{\mathrm{T}}\left(=\mathrm{ATCC} 33337^{\mathrm{T}}\right)$ & $\mathrm{AB} 006761$ & AB014933 \\
\hline Oceanospirillum multiglobuliferum IFO $13614^{\mathrm{T}}\left(=\right.$ ATCC $\left.33336^{\mathrm{T}}\right)$ & AB006764 & AB032186 \\
\hline Oceanospirillum japonicum ATCC $19191^{\mathrm{T}}\left(=\mathrm{IFO} 15446^{\mathrm{T}}\right)$ & AB006766 & AB032187 \\
\hline Oceanospirillum kriegii IFO $15467^{\mathrm{T}}\left(=\right.$ ATCC $\left.27133^{\mathrm{T}}\right)$ & AB006767 & AB032188 \\
\hline Oceanospirillum jannaschii IFO $15466^{\mathrm{T}}\left(=\mathrm{ATCC} 27135^{\mathrm{T}}\right.$ ) & AB006765 & AB014934 \\
\hline Oceanospirillum pusillum IFO $13613^{\mathrm{T}}\left(=\right.$ ATCC $\left.33338^{\mathrm{T}}\right)$ & AB006768 & AB014937 \\
\hline Marinobacterium georgiense ATCC $700074^{\mathrm{T}}$ & U58339 & AB048519 \\
\hline Pseudomonas iners IAM $1419^{\mathrm{T}}$ & AB021408 & AB048520 \\
\hline Pseudomonas stanieri ATCC $27130^{\mathrm{T}}$ & AB021367 & AB048521 \\
\hline Marinospirillum minutulum ATCC $19193^{\mathrm{T}}\left(=\mathrm{IFO} 15450^{\mathrm{T}}\right)$ & AB006769 & AB032189 \\
\hline Marinospirillum megaterium JCM $10129^{\mathrm{T}}$ & AB006770 & AB032190 \\
\hline Marinomonas communis ATCC $27118^{\mathrm{T}}$ & AF173967 & AB014929 \\
\hline Marinomonas vaga ATCC $27119^{\mathrm{T}}$ & X67025 & AB014932 \\
\hline
\end{tabular}

Direct sequencing of the amplified DNA fragments was performed as described previously (Satomi et al., 1997). 16S rDNA sequences used for phylogenetic studies were obtained from the DDBJ database. The accession numbers of the sequences used this study are listed in Table 1.

The $1.4 \mathrm{kbp}$ nucleotide sequences of the $16 \mathrm{~S}$ rRNA gene (covering base positions 66-1448, E. coli numbering) and $1 \cdot 1$ $\mathrm{kbp}$ nucleotide sequences of the $g y r B$ gene (covering base positions 316-1472, E. coli numbering) were used for phylogenetic analysis. Sequence data were edited with the DNASIS software (Takara). In order to search for organisms with phylogenetic relationships to Oceanospirillum species, their $16 \mathrm{~S}$ rDNA sequences were compared to $16 \mathrm{~S}$ rDNA sequence information in the GenBank, EMBL and DDBJ databases by using the BLAST algorithm (Altschul et al., 1990). Sequences that exhibited close relatedness in a BLAST search were used for phylogenetic analysis. Multiple alignment, calculation of nucleotide substitution rates $\left(K_{\text {nuc }}\right.$ values) as described by Kimura (1980) and construction of phylogenetic trees by the neighbour-joining method (Saitou \& Nei, 1987) were performed by using the CLUSTAL W computer program (Thompson et al., 1994). Alignment gaps, primer regions for PCR amplification and unidentified base positions were not taken into consideration for the calculations. The robustness of the topology on phylogenetic trees was evaluated by a bootstrap analysis with 1000 replications.

\section{RESULTS AND DISCUSSION}

Phylogenetic trees of Oceanospirillum strains based on the nucleotide sequences of $16 \mathrm{~S}$ rDNA and $\operatorname{gyr} B$ nucleotide sequences are shown in Fig. 1. The topo- logies of the 16S rDNA- and gyrB-based trees were similar. Four species, Oceanospirillum linum, Oceanospirillum maris (including three subspecies), Oceanospirillum beijerinckii (including two subspecies) and Oceanospirillum multiglobuliferum, formed a strongly supported cluster (bootstrap value $100 \%$ ) within the $\gamma$ Proteobacteria based on 16S rDNA analysis (referred to as the Oceanospirillum core group in this study), with enough distance to separate each other at the species level. The sequence similarity values among the Oceanospirillum core group were more than 95 and $78 \%$, respectively, for $16 \mathrm{~S}$ rDNA and $g y r B$ nucleotide sequences. However, the sequence similarity values between the Oceanospirillum core group and the remaining Oceanospirillum species were less than 90 and $72 \%$, respectively, for $16 \mathrm{~S}$ rDNA and gyr B nucleotide sequences. Oceanospirillum jannaschii, Oceanospirillum japonicum and Oceanospirillum kriegii were assigned within the $\gamma$-Proteobacteria, while Oceanospirillum pusillum was assigned within the $\alpha$ Proteobacteria. These data are in agreement with the earlier finding of Pot et al. (1989), who proposed the removal of Oceanospirillum jannaschii, Oceanospirillum kriegii and Oceanospirillum pusillum from the genus Oceanospirillum on the basis of a polyphasic study in which DNA-rRNA hybridizations played an important role. In that study, Oceanospirillum japonicum was assigned to the genus Oceanospirillum (Pot et al., 1989). However, the present results indicate that its $16 \mathrm{~S}$ rDNA and $g y r B$ sequences are not sufficiently similar to those of strains of the Oceanospirillum core group to be so assigned. 
(a)

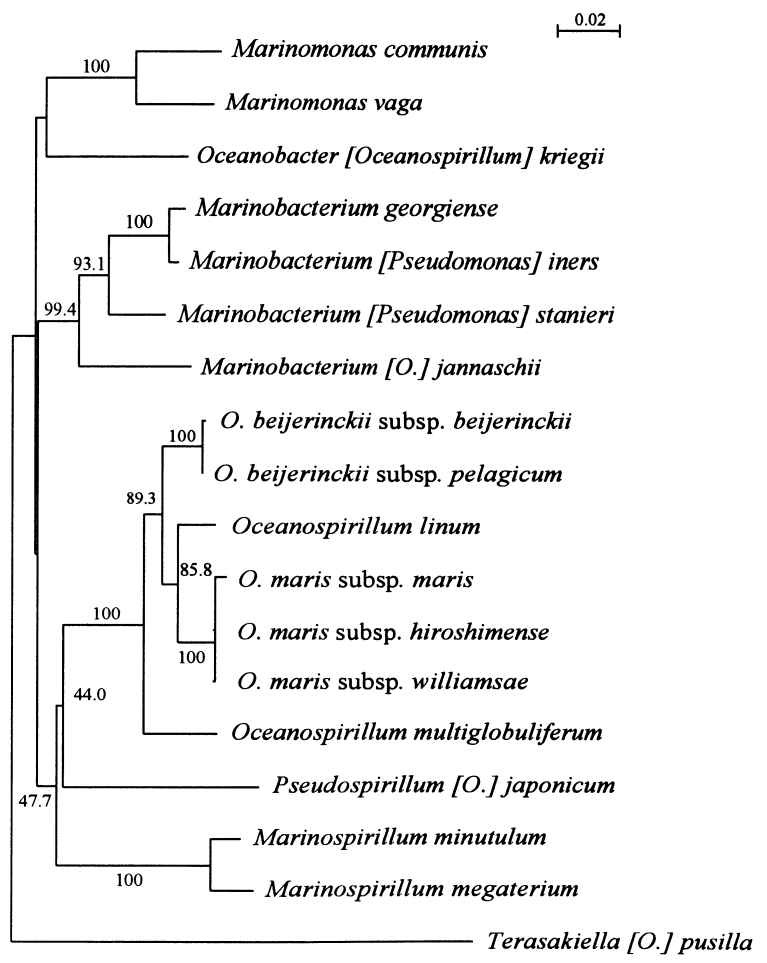

(b) gyrB

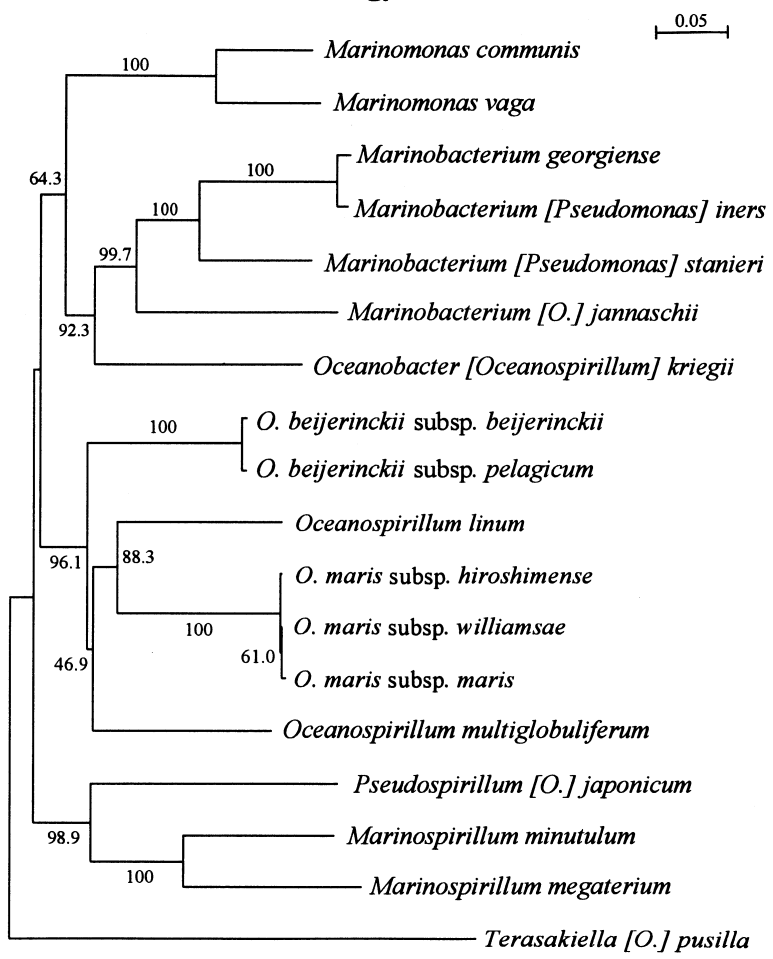

Fig. 1. Phylogenetic trees of the genus Oceanospirillum based on the nucleotide sequences of the $16 \mathrm{~S}$ rRNA (a) and gyrB (b) genes. The trees were constructed by using the neighbour-joining method and nucleotide substitution rates $\left(K_{\text {nuc }}\right.$ values) were computed by Kimura's 2-parameter model. Bars, genetic distance $\left(K_{\text {nuc }}\right)$. Numbers at nodes indicate the percentages of occurrence in 1000 bootstrapped trees. Only values greater than $40 \%$ are shown. O., Oceanospirillum. Terasakiella pusilla was included as an outgroup.

Oceanospirillum jannaschii exhibited close relationships to Marinobacterium georgiense, Pseudomonas iners and Pseudomonas stanieri, with respective $16 \mathrm{~S}$ rDNA similarity values of 93,92 and $95 \%$. These species formed clusters supported by bootstrapping resampling values of more than $99 \%$ in phylogenetic trees based on 16S rDNA and gyrB nucleotide sequences (Fig. 1). Although the phylogenetic distance between Oceanospirillum jannaschii and Marinobacterium georgiense was much larger than that between Pseudomonas stanieri and Marinobacterium georgiense, their DNA base compositions were the same $(55 \mathrm{~mol} \% \mathrm{G}+\mathrm{C})$. This suggested that the four species were related as closely as members of the same genus. Pseudomonas iners and Pseudomonas stanieri were obviously misnamed, since these two species exhibited large phylogenetic distances from the type species of the genus Pseudomonas (Pseudomonas aeruginosa) and its related organisms based on $16 \mathrm{~S}$ rDNA sequence analysis (Anzai et al., 2000). According to the original descriptions of Oceanospirillum jannaschii (Bowditch et al., 1984), Marinobacterium georgiense (González et al., 1997), Pseudomonas iners (Iizuka \& Komagata, 1964) and Pseudomonas stanieri (Baumann et al., 1983), they are all Gram-negative, rod-shaped, motile and strictly aerobic bacteria and they also have similar biochemical characteristics. Therefore, we propose that Oceanospirillum jannaschii and Pseudomonas stanieri be transferred to the genus Marinobacterium as Marinobacterium jannaschii comb. nov. and Marinobacterium stanieri comb. nov. The results of the present study also suggest that there is no significant genotypic or phenotypic difference to justify the separation of Marinobacterium georgiense and Pseudomonas iners. The sequence similarity values between Marinobacterium georgiense and Pseudomonas iners for $16 \mathrm{~S}$ rDNA and gyr $B$ were 99.7 and $98.5 \%$, and the amino acid sequences of GyrB of the two species were identical. The DNA-DNA hybridization value between Marinobacterium georgiense and Pseudomonas iners was $80 \%$ (Table 2), which exceeds the value of $70 \%$ required to consider two strains to be members of the same species (Wayne et al., 1987). Also, their physiological properties as tested by API 20E, API $20 \mathrm{NE}$ and API ZYM were confirmed to be identical except for citrate utilization (negative for Pseudomonas iners) and acid production from rhamnose (negative for Marinobacterium georgiense). According to the Rules of the International Code of Nomenclature of Bacteria (Lapage et al., 1992), Marinobacterium georgiense and Pseudomonas iners should be unified as Marinobacterium georgiense. 
Table 2. Levels of DNA-DNA reassociation among members of Oceanospirillum and related species

\begin{tabular}{|c|c|c|c|c|c|}
\hline \multirow{2}{*}{ Source of unlabelled DNA } & \multicolumn{5}{|c|}{ Relatedness (\%) to labelled DNA from: } \\
\hline & 1 & 3 & 4 & 6 & 9 \\
\hline 1. Oceanospirillum linum IFO $15448^{\mathrm{T}}$ & 100 & 24 & 20 & 25 & NT \\
\hline 2. Oceanospirillum linum IFO 15449 & 94 & NT & NT & 25 & NT \\
\hline 3. Oceanospirillum maris subsp. maris ATCC $27509^{\mathrm{T}}$ & 24 & 100 & 91 & 25 & NT \\
\hline 4. Oceanospirillum maris subsp. hiroshimense IFO $13616^{\mathrm{T}}$ & 20 & 91 & 100 & 20 & NT \\
\hline 5. Oceanospirillum maris subsp. williamsae IFO $15468^{\mathrm{T}}$ & 26 & 89 & 91 & 26 & NT \\
\hline 6. Oceanospirillum beijerinckii subsp. beijerinckii IFO $15445^{\mathrm{T}}$ & 20 & 20 & 18 & 100 & NT \\
\hline 7. Oceanospirillum beijerinckii subsp. pelagicum $\mathrm{IFO} 13612^{\mathrm{T}}$ & 16 & 19 & 18 & 89 & NT \\
\hline 8. Oceanospirillum multiglobuliferum IFO $13614^{\mathrm{T}}$ & 22 & 17 & 13 & 15 & NT \\
\hline 9. Marinobacterium georgiense ATCC $700074^{\mathrm{T}}$ & NT & NT & NT & NT & 100 \\
\hline 10. Pseudomonas iners IAM $1419^{\mathrm{T}}$ & NT & NT & NT & NT & 80 \\
\hline 11. Pseudomonas stanieri ATCC $27130^{\mathrm{T}}$ & NT & NT & NT & NT & 23 \\
\hline 12. Oceanospirillum jannaschii IFO $15466^{\mathrm{T}}$ & 9 & NT & NT & NT & 13 \\
\hline
\end{tabular}

NT, Not tested.

The 16S rDNA sequences of Oceanospirillum japonicum, Oceanospirillum pusillum and Oceanospirillum kriegii were compared with all the sequences available in the DDBJ. No sequence showed identity higher than $90 \%$ to these sequences. The phylogenetic tree based on the nucleotide sequences of 16S rDNA showed that Oceanospirillum japonicum did not cluster with any other known bacterial species (Fig. 1). Although the phylogenetic tree based on gyr B nucleotide sequences showed that Oceanospirillum japonicum and the species of Marinospirillum formed a cluster supported by a high bootstrapping value (98.9\%) (Fig. 1 ), that based on amino acid sequences of GyrB translated from $g y r B$ nucleotide sequence showed that this branch was only weakly supported, with a low bootstrapping value (44.6\% ; data not shown). Moreover, the phylogenetic distance between Oceanospirillum japonicum and the species of Marinospirillum was too large to combine them in the same genus $(88$ and $68 \%$ sequence similarity values for $16 \mathrm{~S}$ rDNA and $\operatorname{gyr} B$ nucleotide sequences). These results indicate that the taxonomic position of Oceanospirillum japonicum is separate from that of the genus Marinospirillum. Likewise, Oceanospirillum pusillum and Oceanospirillum kriegii did not cluster with other known organisms within the $\alpha$-Proteobacteria and $\gamma$-Proteobacteria, respectively. Kawasaki et al. (1997) also reported that Oceanospirillum pusillum did not have a suitable taxonomic position within the $\alpha$-Proteobacteria. These results suggest that Oceanospirillum japonicum, Oceanospirillum pusillum and Oceanospirillum kriegii are clearly distinct from any previously described species at the genus level. Therefore, we propose to create new genera for them.

The present results, indicating the close genetic relationships between the subspecies of Oceanospirillum maris and those of Oceanospirillum beijerinckii, question the validity of the subspecies within these species.
The similarity values between the subspecies of each species for both $16 \mathrm{~S}$ rDNA and gyrB nucleotide sequences were greater than $99 \%$. Moreover, the deduced amino acid sequences of GyrB translated from $\operatorname{gyr} B$ nucleotide sequences were identical for the subspecies of each species. Yamamoto \& Harayama $(1995,1996,1998)$ reported that the resolution of the gyr $B$ nucleotide sequence was much higher than that of $16 \mathrm{~S}$ rDNA because of fast nucleotide substitution caused by the mutation of third codon positions. Although a unified genetic criterion for creating subspecies needs to be established, it is likely that the significant sequence similarity (more than $99 \%$ ) of the gyr $B$ nucleotide sequences corresponds to a genetic distance much closer than that of subspecies. This notion was supported by the results of DNA-DNA hybridization (Table 2). The hybridization value between Oceanospirillum beijerinckii subsp. beijerinckii and Oceanospirillum beijerinckii subsp. pelagicum was $89 \%$ while, between the Oceanospirillum maris subspecies, it was also more than $89 \%$. Pot et al. (1989) also reported the close relationships of these subspecies based on whole-cell protein electrophoresis patterns. Pot et al. (1989, 1992), however, retained these subspecies, citing some differences between these subspecies in the phenotypic data determined previously. These included the optimum temperature for growth, nutrient requirements, the utilization of organic acids, growth in the presence of $1 \%$ glycine and some enzymic activities in Oceanospirillum maris and the range of temperature and $\mathrm{NaCl}$ concentration for growth and the utilization of organic compounds in Oceanospirillum beijerinckii. In this study, we have performed a fresh comparative analysis of the phenotypes of these species, including the ranges of temperature and $\mathrm{NaCl}$ concentration for growth and tests using API 20E, 20NE and API ZYM. The subspecies of Oceanospirillum maris could be differentiated by the optimum temperature for growth and tolerance of $1 \%$ 


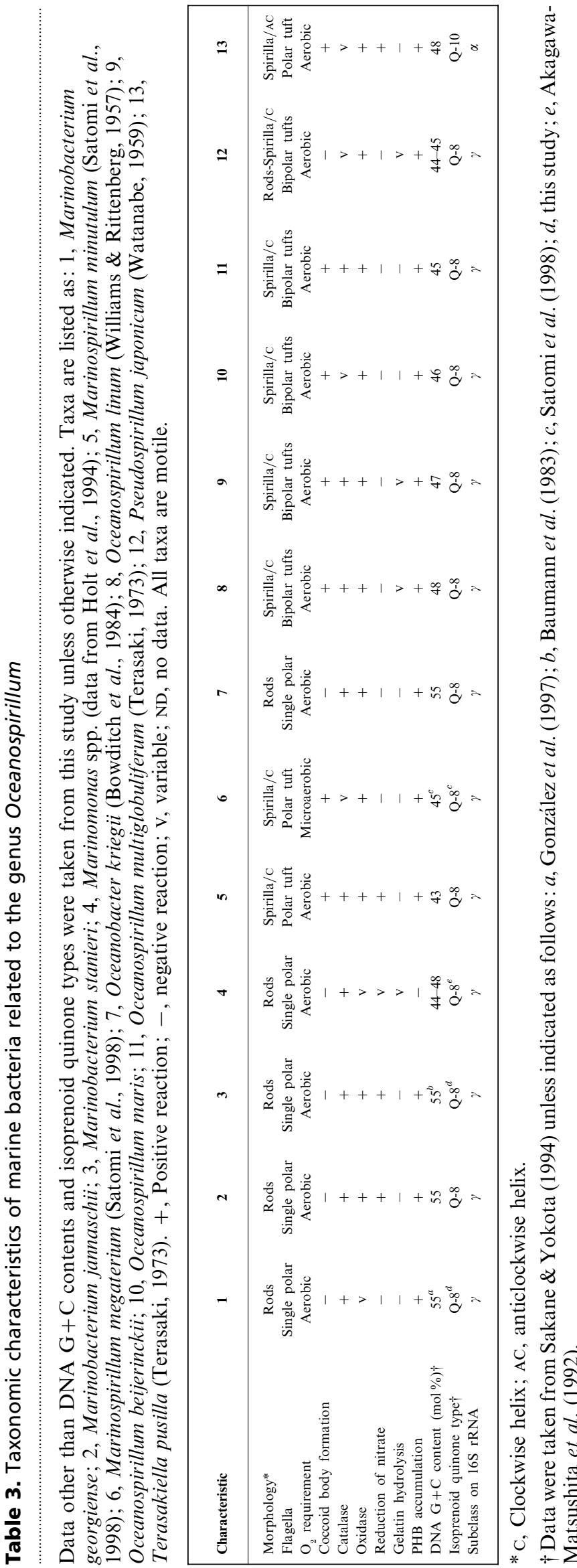

glycine, in accordance with the previous data (Pot et al., 1989). Likewise, the subspecies of Oceanospirillum beijerinckii could be differentiated by their ranges of temperature and $\mathrm{NaCl}$ for growth, in accordance with the previous data (Pot et al., 1989). Other physiological traits tested were identical for the subspecies of each species. Various identical characters of the subspecies of Oceanospirillum maris revealed in this study, such as the production of catalase (negative in all strains), DNase (negative in all strains) and phosphatase (positive in all strains), were originally shown to be different and were used to differentiate them (Pot et al., 1989). Likewise, characters identical for the subspecies of Oceanospirillum beijerinckii such as the utilization of DL-malate and citrate (positive in all strains) were originally shown to differ and were used to differentiate them (Pot et al., 1989). These differences from the previous data are probably due to differences in researchers and methods. At the level of the physiological differences described above, the basis for retaining the subspecies is questioned, since a considerable difference in phenotypes among strains of a species could occur with the current definition of a species (Wayne et al., 1987). Since strains with approximately $70 \%$ DNA-DNA relatedness will logically have at least $2-4 \%$ DNA sequence difference $\left(10^{5}\right.$ nucleotides) (Stackebrandt \& Goebel, 1994), population surveys using more strains should be carried out in future to demonstrate the presence of phenotypically distinct groups within Oceanospirillum maris and Oceanospirillum beijerinckii. Therefore, at present, we propose that the subspecies of Oceanospirillum maris (O. maris subsp. maris, O. maris subsp. hiroshimense and $O$. maris subsp. williamsae) and Oceanospirillum beijerinckii (O. beijerinckii subsp. beijerinckii and $O$. beijerinckii subsp. pelagicum) should be rejected.

Differential characteristics of marine bacteria related to the genus Oceanospirillum are shown in Table 3.

\section{Definition of Oceanospirillum sensu stricto}

From our phylogenetic studies, we conclude that it is logical to eliminate four misplaced Oceanospirillum species, Oceanospirillum pusillum, Oceanospirillum jannaschii, Oceanospirillum japonicum and Oceanospirillum kriegii, from the genus Oceanospirillum and to eliminate the subspecies within each of the species Oceanospirillum maris and Oceanospirillum beijerinckii. Thus, we propose to define the genus Oceanospirillum sensu stricto as including four species, Oceanospirillum linum, Oceanospirillum maris, Oceanospirillum beijerinckii and Oceanospirillum multiglobuliferum. The subspecies of Oceanospirillum maris $(O$. maris subsp. maris, $O$. maris subsp. hiroshimense and $O$. maris subsp. williamsae) and Oceanospirillum beijerinckii $(O$. beijerinckii subsp. beijerinckii and $O$. beijerinckii subsp. pelagicum) should be rejected.

The definitions of the species Oceanospirillum beijerinckii and Oceanospirillum maris remain as their original descriptions (Williams \& Rittenberg, 1957; Hylemon 
et al., 1973) and the original descriptions of Oceanospirillum linum (Williams \& Rittenberg, 1957) and Oceanospirillum multiglobuliferum (Terasaki, 1979) are also unchanged.

\section{Emended description of Oceanospirillum Hylemon et al. $1973^{\mathrm{AL}}$}

Oceanospirillum [O.ce.an.o.spi.ril'lum. Gr. n. okeanos the ocean; N.L. dim. neut. n. spirillum a small spiral from Gr. n. spira spiral; N.L. Oceanospirillum a small spiral organism from the ocean (sea water)].

Rigid, helical cells with clockwise helix. Cells $0 \cdot 4-1 \cdot 2$ $\mu \mathrm{m}$ in diameter; length of the helix, $2 \cdot 0-40 \mu \mathrm{m}$. A polar membrane underlies the cytoplasmic membrane at the cell poles in all species examined so far by electron microscopy. Intracellular poly- $\beta$-hydroxybutyrate (PHB) is formed. All species form thin-walled coccoid bodies, which predominate in old cultures. Gram-negative. Motile by bipolar tufts of flagella. Chemo-organotrophic, having a strictly respiratory type of metabolism with oxygen as the terminal electron acceptor. Nitrate respiration does not occur; nitrate is not reduced to nitrite or beyond the nitrite stage. Optimum temperature, $25-32{ }^{\circ} \mathrm{C}$. Oxidase-positive. Indole-negative. Casein, starch, hippurate and aesculin are not hydrolysed. Sea water required for growth. Carbohydrates are neither fermented nor oxidized. Amino acids or the salts of organic acids serve as carbon sources. Growth factors are not usually required. Isolated from coastal sea water, from decaying seaweed and from putrid infusions of marine mussels. The $\mathrm{G}+\mathrm{C}$ content of the genomic DNA ranges from 45 to $50 \mathrm{~mol} \%$ (as determined by the thermal denaturation method). The type species is Oceanospirillum linum (Williams and Rittenberg 1957) Hylemon et al. $1973^{\mathrm{AL}}$.

\section{Description of Pseudospirillum gen. nov.}

Pseudospirillum (Pseu.do.spi.ril'lum. Gr. adj. pseudes false; N.L. n. Spirillum genus of spiral-shaped bacteria; N.L. n. Pseudospirillum false Spirillum).

Gram-negative, curved, straight or S-shaped, nonspore-forming, halophilic, aerobic, chemo-heterotrophic and PHB-accumulating bacteria. Motile by means of flagella. Oxidase-positive. Catalase-negative or -positive reaction. Carbohydrates are not catabolized. Genomic DNA $\mathrm{G}+\mathrm{C}$ content of $45 \mathrm{~mol} \%$ (as determined by HPLC). The isoprenoid quinone type is Q-8. The type species is Pseudospirillum japonicum comb. nov. (basonym Oceanospirillum japonicum).

\section{Description of Pseudospirillum japonicum comb. nov.}

Basonym: Oceanospirillum japonicum (Watanabe 1959).

The type strain is ATCC $19191^{\mathrm{T}}$. The original description of the species given by Watanabe (1959) is unchanged.

\section{Description of Oceanobacter gen. nov.}

Oceanobacter (O.ce.a.no.bac'ter. Gr. n. okeanos the ocean; L. masc. n. bacter rod; N.L. masc. n. Oceanobacter rod of the sea).

Gram-negative, straight rod-shaped, non-spore-forming, halophilic, aerobic, chemo-heterotrophic and PHB-accumulating bacteria. Motile by means of flagella. Oxidase-positive. Catalase-positive reaction. Carbohydrates are not catabolized. Nitrate is reduced to nitrite. Genomic DNA G $+\mathrm{C}$ content of $55 \mathrm{~mol} \%$ (as determined by HPLC). The isoprenoid quinone type is Q-8. The type species is Oceanobacter kriegii comb. nov. (basonym Oceanospirillum kriegii).

\section{Description of Oceanobacter kriegii comb. nov.}

Basonym: Oceanospirillum kriegii (Bowditch et al. 1984).

The type strain is ATCC $27133^{\mathrm{T}}$. The original description of the species given by Bowditch et al. (1984) is unchanged.

\section{Description of Terasakiella gen. nov.}

Terasakiella (Te.ra.sa.ki.el'la. L. dim. ending -ella; N.L. fem. n. Terasakiella named to honour Y. Terasaki, the Japanese microbiologist, who has made many contributions to our understanding of the classification and identification of spiral-shaped bacteria).

Gram-negative, rigid, helical cells with anticlockwise helix. Non-spore-forming, coccoid body-forming, halophilic, aerobic, chemo-heterotrophic and PHBaccumulating bacteria. Motile by means of flagella. Oxidase-positive. Catalase-negative or -positive reaction. Carbohydrates are not catabolized. Nitrate is reduced to nitrite. Genomic DNA $\mathrm{G}+\mathrm{C}$ content of $48 \mathrm{~mol} \%$ (as determined by HPLC). The isoprenoid quinone type is Q-10. The type species is Terasakiella pusilla comb. nov. (basonym Oceanospirillum pusillum).

\section{Description of Terasakiella pusilla comb. nov.}

Basonym: Oceanospirillum pusillum (Terasaki 1979).

The type strain is IFO $13613^{\mathrm{T}}$. The original description of the species given by Terasaki (1973) is unchanged.

\section{Description of Marinobacterium jannaschii comb. nov.}

Basonym: Oceanospirillum jannaschii (Bowditch et al. 1984).

The type strain is ATCC $27135^{\mathrm{T}}$. Physiological, chemotaxonomic and phylogenetic data indicate that Oceanospirillum jannaschii is more closely related to Marinobacterium georgiense than to Oceanospirillum linum, the type species of the genus Oceanospirillum. The original description of the species given by Bowditch et al. (1984) is unchanged. 


\section{Description of Marinobacterium stanieri comb. nov.}

Basonym: Pseudomonas stanieri (Baumann et al. 1983).

The type strain is ATCC $27130^{\mathrm{T}}$. Physiological, chemotaxonomic and phylogenetic data indicate that Pseudomonas stanieri is more closely related to Marinobacterium georgiense than to Pseudomonas aeruginosa, the type species of the genus Pseudomonas. The original description of the species given by Baumann et al. (1983) is unchanged.

\section{Emended description of Marinobacterium georgiense}

Physiological, chemotaxonomic and phylogenetic data indicate that Marinobacterium georgiense should include strains formerly classified as Pseudomonas iners Iizuka and Komagata 1964. The original description of Marinobacterium georgiense given by González et al. (1997) is unchanged. The type strain is ATCC $700074^{\mathrm{T}}$.

\section{ACKNOWLEDGEMENTS}

The authors thank Dr K. Venkateswaran for helpful discussions and Dr Y. Terasaki for providing us with bacterial strains and for his useful advice. This study was partly supported by a Grant-in-Aid from the Ministry of Education, Science, Sports and Culture of Japan (B 09460094).

\section{REFERENCES}

Akagawa-Matsushita, M., Ito, T., Katayama, Y., Kuraishi, H. \& Yamasato, K. (1992). Isoprenoid quinone composition of some marine Alteromonas, Marinomonas, Deleya, Pseudomonas and Shewanella species. J Gen Microbiol 138, 2275-2281.

Altschul, S. F., Gish, W., Miller, W., Myers, E. W. \& Lipman, D. J. (1990). Basic local alignment search tool. J Mol Biol 215, 403-410.

Anzai, Y., Kim, H., Park, J.-Y., Wakabayashi, H. \& Oyaizu, H. (2000). Phylogenetic affiliation of the pseudomonads based on $16 \mathrm{~S}$ rRNA sequence. Int J Syst Evol Microbiol 50, 1563-1589.

Baumann, L., Baumann, P., Mandel, M. \& Allen, R. D. (1972). Taxonomy of aerobic marine eubacteria. J Bacteriol 110, 402-429.

Baumann, P., Bowditch, R. D., Baumann, L. \& Beaman, B. (1983). Taxonomy of marine Pseudomonas species: P. stanieri sp. nov.; $P$. perfectomarina sp. nov., nom. rev.; $P$. nautica; and $P$. doudoroffii. Int $J$ Syst Bacteriol 33, 857-865.

Bowditch, R. D., Baumann, L. \& Baumann, P. (1984). Description of Oceanospirillum kriegii sp. nov. and $O$. jannaschii sp. nov. and assignment of two species of Alteromonas to this genus as $O$. commune comb. nov. and O. vagum comb. nov. Curr Microbiol 10, 221-230.

Edgell, D. R., Klenk, H.-P. \& Doolittle, W. F. (1997). Gene duplications in evolution of archaeal family B DNA polymerases. $J$ Bacteriol 179, 2632-2640.

Ezaki, T., Hashimoto, Y. \& Yabuuchi, E. (1989). Fluorometric deoxyribonucleic acid-deoxyribonucleic acid hybridization in microdilution wells as an alternative to membrane filter hybridization in which radioisotopes are used to determine genetic relatedness among bacterial strains. Int J Syst Bacteriol 39, 224-229.

González, J. M., Mayer, F., Moran, M. A., Hodson, R. E. \& Whitman, W. B. (1997). Microbulbifer hydrolyticus gen. nov., sp. nov., and Marinobacterium georgiense gen. nov., sp. nov., two marine bacteria from a lignin-rich pulp mill waste enrichment community. Int $J$ Syst Bacteriol 47, 369-376.
Hamana, K., Sakane, T. \& Yokota, A. (1994). Polyamine analysis of the genera Aquaspirillum, Magnetospirillum, Oceanospirillum, and Spirillum. J Gen Appl Microbiol 40, 75-82.

Holt, J. G., Krieg, N. R., Sneath, P. H. A., Staley, J. T. \& Williams, S. T. (editors). (1994). Bergey's Manual of Determinative Bacteriology, 9th edn. Baltimore: Williams \& Wilkins.

Hylemon, P. B., Wells, J. S., Jr, Krieg, N. R. \& Jannasch, H. W. (1973). The genus Spirillum: a taxonomic study. Int J Syst Bacteriol 23, 340-380.

IFO (1996). List of media. In List of Cultures. Microorganisms, 10th edn, p. 515. Edited by Institute for Fermentation, Osaka (IFO). Osaka: Institute for Fermentation.

lizuka, H. \& Komagata, K. (1964). Microbiological studies on petroleum and natural gas. II. Determination of pseudomonads isolated from oil-brines and related materials. J Gen Appl Microbiol 10, 223-231.

Kawasaki, H., Yamasato, K. \& Sugiyama, J. (1997). Phylogenetic relationships of the helical-shaped bacteria in the alpha Proteobacteria inferred from 16S rDNA sequences. J Gen Appl Microbiol 43, 89-95.

Kimura, M. (1980). A simple method for estimating evolutionary rates of base substitutions through comparative studies of nucleotide sequences. J Mol Evol 16, 111-120.

Lapage, S. P., Sneath, P. H. A., Lessel, E. F., Skerman, V. B. D., Seeliger, H. P. R. \& Clark, W. A. (editors) (1992). International Code of Nomenclature of Bacteria (1990 Revision). Bacteriological Code. Washington, DC: American Society for Microbiology.

Linn, D. M. \& Krieg, N. R. (1978). Occurrence of two organisms in cultures of the type strain of Spirillum lunatum: proposal for rejection of the name Spirillum lunatum and characterization of Oceanospirillum maris subsp. williamsae and an unclassified vibrioid bacterium. Request for an Opinion. Int J Syst Bacteriol 28, 132-138.

Morse, R., Collins, M. D., O'Hanlon, K., Wallbanks, S. \& Richardson, P. T. (1996). Analysis of the $\beta^{\prime}$ subunit of DNA-dependent RNA polymerase does not support the hypothesis inferred from 16S rRNA analysis that Oenococcus oeni (formerly Leuconostoc oenos) is a tachytelic (fast-evolving) bacterium. Int J Syst Bacteriol 46, 1004-1009.

Pot, B., Gillis, M., Hoste, B., Van De Velde, A., Bekaert, F., Kersters, K. \& De Ley, J. (1989). Intra- and intergeneric relationships of the genus Oceanospirillum. Int J Syst Bacteriol 39, 23-34.

Pot, B., Gillis, M. \& De Ley, J. (1992). The genus Oceanospirillum. In The Prokaryotes: a Handbook on the Biology of BacteriaEcophysiology, Isolation, Identification, Applications, 2nd edn, vol. 4, pp. 3230-3236. Edited by A. Balows, H. G. Trüper, M. Dworkin, W. Harder \& K.-H. Schleifer. New York: Springer.

Saitou, N. \& Nei, M. (1987). The neighbor-joining method: a new method for reconstructing phylogenetic trees. Mol Biol Evol 4, 406-425.

Sakane, T. \& Yokota, A. (1994). Chemotaxonomic investigation of heterotrophic, aerobic and microaerophilic spirilla, the genera Aquaspirillum, Magnetospirillum, and Oceanospirillum. Syst Appl Microbiol 17, 128-134.

Sambrook, J., Fritsch, E. F. \& Maniatis, T. (1989). Molecular Cloning: a Laboratory Manual, 2nd edn. Cold Spring Harbor, NY: Cold Spring Harbor Laboratory.

Satomi, M., Kimura, B., Mizoi, M., Sato, T. \& Fujii, T. (1997). Tetragenococcus muriaticus sp. nov., a new moderately halophilic lactic acid bacterium isolated from fermented squid liver sauce. Int $J$ Syst Bacteriol 47, 832-836.

Satomi, M., Kimura, B., Hayashi, M., Shouzen, Y., Okuzumi, M. \& Fujii, T. (1998). Marinospirillum gen. nov., with descriptions of Marinospirillum megaterium sp. nov., isolated from kusaya gravy, and transfer of Oceanospirillum minutulum to Marinospirillum minutulum comb. nov. Int J Syst Bacteriol 48, 1341-1348.

Stackebrandt, E. \& Goebel, B. M. (1994). Taxonomic note: a place for DNA-DNA reassociation and 16S rRNA sequence analysis in the present species definition in bacteriology. Int J Syst Bacteriol 44, 846-849.

Takewaki, S., Okuzumi, K., Manabe, I., Tanimura, M., Miyamura, K., Nakahara, K., Yazaki, Y., Ohkubo, A. \& Nagai, R. (1994). Nucleotide sequence comparison of the mycobacterial dnaJ gene and 
PCR-restriction fragment length polymorphism analysis for identification of mycobacterial species. Int J Syst Bacteriol 44, 159-166.

Terasaki, Y. (1972). Studies on the genus Spirillum Ehrenberg. I. Morphological, physiological, and biochemical characteristics of water spirilla. Bull Suzugamine Women's Coll Nat Sci 16, 1-146.

Terasaki, Y. (1973). Studies on the genus Spirillum Ehrenberg. II. Comments on type and reference strains of Spirillum and description of new species and subspecies. Bull Suzugamine Women's Coll Nat Sci 17, 1-71.

Terasaki, Y. (1975). Freeze-dried cultures of water spirilla made on an experimental basis. Bull Suzugamine Women's Coll Nat Sci 19, 1-10.

Terasaki, Y. (1979). Transfer of five species and two subspecies of Spirillum to other genera (Aquaspirillum and Oceanospirillum), with emended descriptions of the species and subspecies. Int $J$ Syst Bacteriol 29, 130-144.

Thompson, J. D., Higgins, D. G. \& Gibson, T. J. (1994). ClustaL w: improving the sensitivity of progressive multiple sequence alignment through sequence weighting, position-specific gap penalties and weight matrix choice. Nucleic Acids Res 22, 4673-4680.

Viale, A. M., Arakaki, A. K., Soncini, F. C. \& Ferreyra, R. G. (1994). Evolutionary relationships among eubacterial groups as inferred from
GroEL (chaperonin) sequence comparisons. Int J Syst Bacteriol 44, 527-533.

Watanabe, N. (1959). On four new halophilic species of Spirillum. Bot Mag (Tokyo) 72, 77-86.

Wayne, L. G., Brenner, D. J., Colwell, R. R. \& 9 other authors (1987). Report of the ad hoc committee on reconciliation of approaches to bacterial systematics. Int J Syst Bacteriol 37, 463-464.

Williams, M. A. \& Rittenberg, S. C. (1957). A taxonomic study of the genus Spirillum Ehrenberg. Int Bull Bacteriol Nomencl Taxon 7, 49-111.

Yamamoto, S. \& Harayama, S. (1995). PCR amplification and direct sequencing of $g y r B$ genes with universal primers and their application to the detection and taxonomic analysis of Pseudomonas putida strains. Appl Environ Microbiol 61, 1104-1109.

Yamamoto, S. \& Harayama, S. (1996). Phylogenetic analysis of Acinetobacter strains based on the nucleotide sequences of $g y r B$ genes and on the amino acid sequences of their products. Int $J$ Syst Bacteriol 46, 506-511.

Yamamoto, S. \& Harayama, S. (1998). Phylogenetic relationships of Pseudomonas putida strains deduced from the nucleotide sequences of gyr B, rpoD and 16S rRNA genes. Int J Syst Bacteriol 48, 813-819. 